Fikrah: Jurnal Ilmu Aqidah dan Studi Keagamaan

issn 2354-6147 eissn 2476-9649

Tersedia online di: journal.stainkudus.ac.id/index.php/Fikrah

DOI: https://doi.org/10.21043/fikrah.v4i1.1663

Artikel diserahkan : 31 Agustus 2016; Diterima: 3 Oktober 2016

\title{
Pendidikan Islam Multikultural Sebagai Resolusi Konflik Agama di Indonesia
}

\author{
Inayatul Ulya \\ Institut Pesantren Mathali'ul Falah (IPMAFA) Pati, Indonesia \\ ulyain@yahoo.com
}

\author{
Ahmad Afnan Anshori \\ UIN Walisongo Semarang, Indonesia \\ afnanshori@gmail.com
}

\begin{abstract}
Abstrak
Artikel ini melihat kemajemukan masyarakat Indonesia, baik agama, ras, suku dan budaya yang seringkali berpotensi pada munculnya berbagai konflik, seiring dengan semakin dinamisnya masyarakat yang mengelompokkan diri dalam berbagai organisasi sosial keagamaan serta lahirnya berbagai aliran keagamaan. Munculnya konflik dengan mengatasnamakan agama merupakan indikator bahwa Bangsa Indonesia masih belum memahami secara utuh kondisi internal yang multikultural. Perbedaan masyarakat seharusnya menjadi dasar untuk mempertahankan identitas dengan menjaga integrasi bangsa, bukan sebagai pemicu konflik antar kelompok. Melalui pendidikan Islam multikultural, tulisan ini memberikan alternatif resolusi konflik agama di Indonesia berdasarkan nilai-nilai yang terkandung dalam ajaran Islam. Pendidikan Islam multikultural dapat dijadikan sebagai pendekatan baru untuk merubah cara berfikir dan cara pandang masyarakat serta keterampilan bersikap juga berperilaku dalam kehidupan yang majemuk. Dalam konteks ini, pendidikan Islam multikultural memberikan penanaman spirit kehidupan beragama yang dilandasi nilai-nilai perdamaian, toleransi, menghargai perbedaan dan sikapsikap lain yang menjunjung tinggi nilai kemanusiaan dan semangat persatuan Kebangsaan Indonesia.
\end{abstract}

Kata Kunci: Agama, masyarakat, multikultural, pendidikan islam, resolusi konflik. 


\begin{abstract}
This article describes the diversity of Indonesian society consisting of religion, race, ethnicity and culture which are often potentially the emergence of various conflicts, along with the dynamic people classifying them in various social and religious organizations as well as the birth of the various religious denominations. Conflicts with the name of religion are an indicator that the Indonesian people do not comprehend the internal conditions of the multicultural. Differences in society should be the basis for maintaining the identity by maintaining national integration and they do not become the cause of conflict among the groups. Through Islamic multicultural education, this article provides an alternative resolution of religious conflicts in Indonesia based on the values contained in the teachings of Islam. Islamic multicultural education can be used as a new approach to change the way of thinking and people's view and skills to be well behaved in the life of diversity. In this context, Islamic multicultural education provides the spirit of religious life based on the values of peace, tolerance, respect for differences and attitudes of others who uphold human values and the spirit of unity of Indonesian Nationality
\end{abstract}

Keywords: religion, society, multicultural, islamic education, conflict resolution.

\title{
Pendahuluan
}

Agama pada dasarnya memiliki peranan yang sangat penting bagi kehidupan manusia, karena agama merupakan sistem nilai yang di dalamnya terdapat normanorma yang mengatur pola perilaku manusia, baik dalam kehidupannya sebagai individu maupun dalam kehidupan bermasyarakat. Sehingga, agama dalam hal ini berfungsi sebagai pedoman hidup dan sekaligus memberi solusi pada munculnya persoalan-persoalan dalam kehidupan ini.

Terlepas dari hal ideal yang diperankan agama, ternyata agama tidak seindah konsep awalnya ketika diamalkan pemeluknya dalam kehidupan, realitas menunjukkan bukti-bukti munculnya berbagai kekerasan, persengketaan, perpecahan bahkan pertumpahan darah, sering terjadi dengan dalih agama. Beberapa konflik antar umat beragama diantaranya konflik antar umat beragama di Moro Filipina (Islam dan Kristen), pembantaian muslim Rohingnya di Myammar (Budha dan Islam), bentrokan sektarian di kota Boda, Republik Afrika Tengah (Islam dan Kristen). Sedangkan di Indonesia beberapa konflik antar agama misalnya konflik yang terjadi di Poso antara umat Islam dengan Kristen yang terjadi sampai beberapa kali, tahun 1992, 1995, 1998, 2000, dan tahun 2001. Selain itu, di Jawa Timur juga terjadi konflik Sunni Syiah (antar aliran agama) tahun 2012 dan masih banyak lagi kasus-kasus yang lain seperti kasus di Ambon, Situbondo, pembakaran tempat ibadah Kaum Ahmadiyah dan Gafatar dan kasus di Tolikara Papua. 
Apapun alasannya konflik antar agama dan konflik atas nama agama tidak dapat dibenarkan karena dapat berdampak pada korban nyawa, kerugian material dan bahkan mengancam terjadinya disintegrasi bangsa. Meskipun, apabila diteliti lebih jauh, konflik-konflik antar agama dan atas nama agama tersebut tidak selalu terkait dengan agama, tetapi banyak faktor-faktor lain yang berada di luar lingkup agama itu sendiri (Effendi, 2001, hal. 24). Misalnya Barat mengadakan invasi ke negara-negara Islam Timur Tengah pada rentang abad ke-18 sampai abad ke-19 dengan tujuan merebut sumber daya alam dan membuka pasar baru (Huntington, 1998, hal. 14). Sehingga, pada akhirnya agama hanya dijadikan kambing hitam dan dasar legitimasi terhadap berbagai kepentingan politik, sosial dan ekonomi kelompok-kelompok tertentu. Agama seringkali dieksploitasi dan dipersalahkan karena dianggap sebagai penyebab munculnya berbagai problem sosial, termasuk perpecahan masyarakat dan perpecahan agama yang berimplikasi pada ketidakstabilan negara. Menurut Abed (1998, hal. 189-201) pada dasarnya sumber konflik itu bukan semata-mata agama, melainkan proses ternbentuknya suatu masyarakat ekonomi baru yang menimbulkan persaingan (competition), sebagai suatu bentuk konflik yang telah direduksi menjadi konflik yang dikendalikan, berdasarkan kerangka aturan main yang direncanakan disepakati (Rahardjo, 1999, hal. 178).

Indonesia sebagai negara yang majemuk memiliki berbagai keanekaragaman suku, ras, budaya, bahasa dan agama. Dalam hal agama, Indonesia mengakui beberapa agama, yaitu Islam, Kristen Katolik, Protestan, Hindu dan Budha. Agamaagama tersebut memiliki prinsip-prinsip dan keyakinan yang berbeda. Sehingga, apabila perbedaan tersebut tidak dikelola dengan baik, rawan menimbulkan persengketaan dan konflik antar agama yang justru bertentangan prinsip agama itu sendiri yang seharusnya mengajarkan nilai-nilai perdamaian.

Dalam menyikapi perbedaan-perbedaan tersebut, prinsip hidup berbangsa dan bernegara harus selalu dijunjung tinggi, semboyan Bhineka Tunggal Ika hendaklah selalu terpatri dalam semangat hidup berbangsa, nilai-nilai persatuan dalam Sumpah pemuda menjadi kekuatan untuk membangun nasionalisme serta nilai-nilai luhur yang terkandung dalam Pancasila dapat menjadi way of life bagi Bangsa Indonesia dalam kehidupan sehari-hari. Dalam rangka mentransformasikan nilai-nilai Pancasila dan prinsip-prinsip hidup berbangsa dan bernegara tesebut diperlukan perantara atau media agar mencapai hasil yang maksimal. Sedangkan media yang dapat digunakan adalah pendidikan Islam multikultural. Konsep pendidikan Islam multikultural ini menawarkan sebuah format pendidikan yang mengakomodir perbedaan yang nilai-nilainya didasarkan pada nilai-nilai yang terkandung dalam al-Quran dan Hadis serta berdasarkan pada makna Pancasila sebagai pandangan hidup dalam kehidupan berbangsa dan bernegara.

Lebih lanjut, tulisan ini difokuskan pada pembahasan mengenai urgensi pendidikan multikultural di Indonesia, akar terbentuknya konflik agama dan pendidikan Islam multikultural sebagai resolusi konflik agama di Indonesia. 


\section{Urgensi Pendidikan Multikultural di Indonesia}

Indonesia merupakan negara yang memiliki bangsa yang majemuk dan multikultural. Pemaknaan majemuk di sini yaitu bangsa dari kelompok masyarakat yang memiliki latar belakang adat istiadat, budaya, agama, dan kepentingan atau masyarakat yang terdiri dari dua atau lebih elemen yang hidup sendiri-sendiri dalam suatu kesatuan politik (Suryana dan Rusdiana, 2015, hal. 3). Sedangkan multikultural adalah keanekaragaman budaya. Istilah multikultural tersebut telah membentuk sebuah ideologi yang disebut dengan multikulturalisme, yaitu sebuah ideologi yang mengakui dan mengagungkan perbedaan dalam kesederajatan. Definisi tersebut kemudian disederhanakan menjadi ideologi yang mengakomodir keberagaman budaya baik dalam hal agama, etnis, ras, bahasa, geografis dan budaya (Lash dan Featherstone, 2002, hal. 2-6). Kemajemukan tersebut digambarkan seperti pisau bermata dua. Satu sisi menampilkan efek positif dan sisi yang lain menampilkan dampak negatif. Sisi positifnya terlihat pada kekayaan dan keragaman budaya yang dimiliki Bangsa Indonesia. Sedangkan sisi negatifnya menunjukkan bahwa keragaman tersebut rawan terhadap terjadinya konflik antar kelompok masyarakat yang berdampak pada instabilitas keamanan, sosial, politik dan ekonomi (Suryana dan Rusdiana, 2015, hal. 254).

Menyikapi keberagaman tersebut, Bangsa Indonesia memerlukan strategi baru dan kerangka berfikir yang lebih toleran dan akomodatif terhadap perbedaan untuk mencegah timbulnya benturan antar budaya, benturan kepentingan kelompok tertentu dan sikap fanatisme yang berlebihan terhadap kelompoknya sendiri sehingga perbedaan dan keragaman tersebut tidak disikapi sebagai ancaman yang dapat berdampak pada persengketaan, konflik dan bahkan aksi-aksi anarkis yang dapat memecah belah persatuan bangsa.

Multikultural dalam hal ini menjadi respon sebuah kebijakan baru terhadap banyaknya keberagaman. Artinya, pengakuan terhadap keberagaman ini tidak cukup tanpa adanya kebijakan untuk bersikap adil dan memberi perlakuan sama terhadap komunitas yang beragam tersebut. Sehingga, multikultural sebagai sebuah gerakan kemudian menuntut pengakuan (politic of recognition) untuk diterima, dihargai dan mendapat perlindungan. Politic of recognition ini awalnya merupakan gagasan politik yang dikemukakan oleh Charles Taylor yang didasarkan pada beberapa hal. Pertama, persamaan harkat dan martabat manusia. Kedua, Pada dasarnya kebudayaan yang berkembang di masyarakat berbeda-beda dan masingmasing membutuhkan pengakuan dan perlindungan. Ketiga, Pengakuan negara dan elemen sosial lain terhadap berbagai bentuk perbedaan budaya tersebut (Taylor, 1994, hal. 18).

Terlepas dari pentingnya pengakuan terhadap keberagaman bangsa tersebut. Bangsa Indonesia tetap harus mempertahankan nilai-nilai otentik bangsa agar Bangsa Indonesia tetap survive dalam menghadapi perubahan global (Tilaar, 2015, hal. 43). Artinya, keanekaragaman yang dimiliki bangsa tetap harus dalam bingkai Bhineka Tunggal Eka, patuh terhadap Pancasila sebagai dasar dan falsafah negara dan UUD 1945 sebagai konstitusi Negara Indonesia. 
Penghargaan terhadap keberagaman adalah faktor yang menjadikan kehidupan masyarakat menjadi harmonis, bersatu dan damai di dalam perbedaan, tetapi juga harus ada common values atau nilai yang harus dijunjung tinggi oleh segenap elemen masyarakat yang plural tersebut (Yusuf, 2011, hal. 89). Nilai-nilai tersebut menjadi nilai yang disepakati oleh Bangsa Indonesia yang akan menjadi pemersatu masyarakat yang multikultural tersebut.

Pendidikan dalam hal ini dapat dijadikan media untuk membangun kesadaran akan pentingnya multikulturalisme. Secara ideal, pendidikan dianggap mampu untuk menjadi penghubung bagi terciptanya dasar kehidupan bangsa yang multikultural dan terbebas dari kooptasi negara. Pergeseran paradigma menuju pada penghargaan atas perbedaan tersebut dapat terealisir apabila ada perubahan paradigma dalam pendidikan, yaitu dari penyeragaman menuju identitas tunggal kemudian diarahkan pada penghargaan keragaman identitas dalam rangka menciptakan harmoni kehidupan (Hilmi, 2003, hal. 332-333).

Pendidikan di era multikultural ini memegang peranan yang sangat menentukan terhadap eksistensi dan perkembangan masyarakat, karena pendidikan merupakan sebuah proses dan usaha mentransformasikan nilai-nilai Islam kepada generasi penerusnya (Arifin, 2011, hal. 8). Pendidikan juga didefinisikan sebagai usaha yang bersifat mendidik, membimbing, mempengaruhi dan mengarahkan tentang suatu ilmu pengetahuan (Saebani dan Hendra, 2012, hal. 21-22). Pendidikan juga diartikan sebagai usaha dalam pergaulan anak untuk mengembangkan perkembangan jasmani dan rohani ke arah kedewasaan (Purwanto, 2011, hal. 11). Konseptualisasi tentang pendidikan tersebut kemudian disandingkan dengan multikultural.

Multikultural secara etimologis dibentuk dari kata multi yang berarti banyak dan kultur yang bermakna budaya. Sehingga, multikultural mengandung makna pengakuan terhadapmartabatmanusiasesuaidengan kebudayaannya masing-masing (Mahfud, 2006, hal. 75). Sehingga Pendidikan multikultural dapat didefinisikan sebagai seperangkat kepercayaan yang mengakui pentingnya penghargaan tentang keragaman budaya dan etnis dalam pengalaman sosial, gaya hidup, identitas pribadi, kesempatan pendidikan, kelompok dan negara (Banks, 1993, hal. 3).

Pendidikan multikultural juga diartikan sebagai sebuah pendekatan dalam belajar mengajar yang didasarkan pada keberagaman nilai dan kepercayaan dan menekankan pada penghargaan budaya yang beracam-macam dari berbagai kelompok sosial (Bennet, 1995, hal. 13). Sehingga, pendidikan multikultural merupakan gerakan pembaharuan dalam bidang pendidikan sebagai bentuk respon pendidikan terhadap perubahan masyarakat yang semakin beragam dan masingmasing membutuhkan pengakuan dan penghargaan akan eksistensinya. Dalam konteks Negara Indonesia, keragaman tersebut dihormati selagi tidak bertentangan dengan dasar falsafah negara dan nilai-nilai yang dijunjung tinggi oleh Bangsa Indonesia. 
Berdasarkan cepatnya dinamika dan keberagaman budaya masyarakat, pendidikan multikultural diperlukan bagi masyarakat di Indonesia karena beberapa hal, diantaranya adalah:

Pertama, pendidikan multikultural dapat dijadikan media untuk resolusi konflik. Berbagai fenomena konflik di tengah-tengah masyarakat yang terjadi akhirakhir ini membutuhkan solusi dengan cara membangun sikap toleransi antara masyarakat karena perbedaan adalah sebuah keniscayaan dalam realitas kehidupan. Pendidikan multikultural dalam hal ini membantu mereposisi perbedaan tersebut sebagai sebuah aset yang dapat dikembangkan sesuai dengan potensi masing-masing dan bukan menjadi sarana konflik yang berujung pada persengketaan, perpecahan atau bahkan sampai pertumpahan darah.

Kedua, Pendidikan multikultural dapat menjadi media untuk melestarikan kebudayaan. Pada era globalisasi yang ditopang dengan kecanggihan teknologi dan akses internet yang semakin menjadi gaya hidup masyarakat, maka berbagai budaya dimanapun dan kapanpun akan semakin mudah diakses oleh seluruh masyarakat Indonesia. Kecenderungan pada trend masa kini dan budaya pop yang sedang berkembang di masyarakat, terutama di sosial media menjadi fenomena yang memprihatinkan, apalagi apabila kecenderungan tersebut berdampak pada krisis identitas diri. Maka budaya sendiri terlupakan dan tercerabut dari akarnya sehingga mengikuti budaya lain yang belum tentu sesuai dengan prinsip-pinsip yang dianut oleh bangsa sendiri. Idealnya pendidikan multikultural dapat membekali masyarakat Indonesia tentang varian budaya Indonesia dan nilai-nilai yang terkandung di dalamnya serta membangun sikap dan rasa bangga terhadap budaya yang dimiliki oleh bangsa Indonesia sendiri.

Ketiga, pendidikan multikultural memberi motivasi bagi munculnya kreativitas dan inovasi dalam masyarakat. Penghargaan terhadap keberagaman budaya masyarakat akan berkontribusi positif terhadap tumbuhnya budaya kreatif dan inovatif anak bangsa untuk berpacu meraih prestasi yang gemilang. Sehingga, keberagaman tidak akan menjadi penghambat tetapi justru menjadi media untuk meningkatkan daya saing dengan tetap menjunjung tinggi sportifitas dan semangat persatuan dalam bingkai satu bangsa, satu tanah air dan berkompetisi untuk selalu memberikan yang terbaik bagi kemajuan bangsa dan negara.

Keempat, pendidikan multikultural dapat menjadi landasan pengembangan kurikulum pendidikan. Kurikulum sebagai seperangkat rencana untuk mencapai tujuan pendidikan semestinya harus selalu responsif terhadap dinamika dan kebutuhan masyarakat khususnya terkait kebutuhan akan pengakuan terhadap keberagaman. Memasukkan nilai-nilai multikultural tersebut dimulai dari rencana pengembangan kurikulum berbasis multikultural. Pengembangan kurikulum tersebut meliputi perubahan terhadap filosofi kurikulum yang secara operasional dicantumkan dalam visi, misi dan tujuan penyelenggaraan pendidikan. Selain itu, nilai-nilai multikultural juga dimasukkan dalam proses belajar di kelas yang meliputi tujuan instruksional dan kesesuaiannya dengan materi ajar, metode dan 
media yang diterapkan dalam pembelajaran. Nilai-nilai multikultural juga dapat dikembangkan di kegiatan pengembangan diri peserta didik serta terinternalisasi dalam kultur sekolah.

Pentingnya memasukkan nilai-nilai multikultural tersebut idealnya tidak hanya dalam pendidikan formal saja. Tetapi harus dibangun melalui lembaga pendidikan keluarga dan masyarakat. Karena, berhasil atau tidaknya sebuah proses pendidikan tergantung dari fungsi sinergis yang dibangun oleh ketiga lembaga pendidikan yang dikenal dengan tripusat pendidikan, yaitu lembaga pendidikan sekolah, keluarga dan masyarakat.

\section{Akar Terbentuknya Konflik Antar Agama}

Agama seharusnya dapat memainkan peran sebagai penyeimbang kehidupan masyarakat di berbagai bidang seperti bidang politik, sosial, ekonomi, pendidikan, ilmu pengetahuan, teknologi dan lain sebagainya. Agama seharusnya juga mampu menjadi dasar acuan manusia dalam menjalani kehidupan bermasyarakat yang baik serta mentaati norma-norma atau peraturan yang ada. Selain itu, agama juga mampu menjadi sumber nilai, kepercayaan dan pola-pola tingkah laku yang dapat memberi tuntunan bagi hakekat, tujuan, dan kestabilan hidup umat manusia karena kehidupan menuntut adanya tuntunan hidup yang mutlak.

Masalah konflik antar agama dan konflik internal agama di Indonesia merupakan sebuah masalah yang serius. Berbagai kasus konflik atas nama agama, baik antar agama maupun konflik dalam suatu agama tertentu sering mewarnai perjalanan kehidupan bangsa Indonesia. Banyak kerugian material, kerugian psikis dan korban yang berjatuhan sebagai akibat dari konflik antar agama.

Beberapa fenomena konflik yang terjadi pada saat ini, agama tidak hanya difahami sebagai sebuah doktrin yang harus diikuti dan memberi identitas bagi pemeluknya saja, tetapi oleh sebagian masyarakat Indonesia mengarah kepada sebuah gerakan. Agama pada akhirnya tidak hanya merupakan suatu kebutuhan psikologis, namun juga membangun tembok pemisah dan berakibat pada pertentangan kepentingan-kepentingan duniawi antar anggota dan komunitas agama yang berbeda-beda (Musahadi, 2007, hal. 81).

Perbedaan agama dalam masyarakat Indonesia yang multikultural adalah sebuah keniscayaan, sehingga idealnya hal ini sudah dipahami masyarakat Indonesia sebagai sebuah konsekuensi hidup di tengah-tengah negara yang multikultur karena segala sesuatu pasti mempunyai sisi positif dan negatif. Begitupun pula keadaan masyarakat Indonesia yang multikultural. Sisi positifnya, masyarakat Indonesia memiliki keanekaragaman yang masing-masing elemen memiliki keunikan tersendiri dari masing-masing masyarakat. Tetapi sisi negatifnya juga rentan terjadi pada sistem masyarakat multikultural. Misalnya terdapat perbedaan pola pikir dari berbagai macam latar belakang kehidupan masyarakat yang banyak dipengaruhi oleh latar belakang agama, karakteristik daerah, adanya pengelompokan dan klaim minoritas dan mayoritas dan lain-lain. 
Apabila sisi negatif kehidupan multikultural tersebut yang lebih dominan, maka akan terjadi konflik-konflik yang berkepanjangan. Konflik dalam kawasan agama kemudian dapat merebak menjadi saling tuding atas dasar perbedaan agama dan keyakinan, klaim benar salah, fanatisme yang berlebihan dan juga masih banyak alasan lain yang kemudian memungkinkan kelompok yang berseteru tersebut melakukan aksi-aksi anarkis yang dapat berakibat pada munculnya teror, kekerasan, pembakaran simbol-simbol agama tertentu yang dapat mengancam terjadinya disintegrasi bangsa.

Akar terbentuknya konflik antar agama tersebut dapat dipetakan menjadi dua faktor, faktor internal dan eksternal. Faktor internal merupakan pemicu yang berasal dari agama itu sendiri. Faktor ini dapat dikelompokkan menjadi beberapa sebab:

Pertama, perbedaan dalam memahami doktrin agama. Masing-masing agama memiliki dasar pemahaman yang berasal dari kitab suci. Dalam perkembangannya banyak persoalan-persoalan kehidupan yang belum bisa terjawab oleh agama melalui pemahaman tekstual dari kitab suci tersebut, sehingga pola-pola pengembangan pemikiran melalui interpretasi teks dengan berbagai pendekatan diperlukan dalam rangka menjawab persoalan-persoalan tersebut. Akan tetapi, interpretasi tersebut sering kali menimbulkan polemik karena perbedaan penafsiran dan perbedaan memahami doktrin agama. Hal semacam ini hampir dialami oleh semua agama. Akibatnya, klaim terhadap kebenaran menjadi tidak dapat terelakkan. Kecenderungan yang muncul, umat beragama berupaya membenarkan ajaran agamanya masing-masing, dan sekaligus menyalahkan ajaran agama lain. Bahkan klaim kebenaran juga terjadi dalam satu agama karena mereka mengklaim telah memahami secara benar apa yang menjadi maksud dari sebuah ajaran tersebut. Keyakinan tersebut pada akhirnya berubah menjadi suatu pemaksaan konsepkonsep gerakannya kepada orang lain yang berbeda keyakinan dan pemahaman dengan mereka. Ajaran agama dalam hal ini tetap diposisikan sebagai doktrin, tetapi seringkali terjadi subjektivitas penafsiran dalam memahami teks-teks kitab suci dalam kehidupan beragama, sehingga sebagian pemeluk agama melegitimasi kekerasan atas nama agama. Padahal kekerasan dari perspektif agama manapun tidak dibenarkan, khususnya Islam yang mendeklarasikan kedamaian sebagai inti ajarannya. Maka, pemeluk agamalah yang seharusnya memiliki kesadaran untuk dapat kreatif dalam memaknai dan membumikan apa yang disyariatkan oleh Allah (Iqbal, 1960, hal. 133).

Kedua, fanatisme agama yang berlebihan. Sikap fanatik yang berlebihan ini juga menjadi pemicu munculnya konflik antar agama. Semua agama memiliki kecenderungan dan mengakomodir perang atas nama agama. Fanatisme ini terjadi karena faktor ideologis mengenai pemaknaan ajaran agama yang cenderung dogmatis dan faktor identitas yang memahami agama dan pemeluknya merupakan satu kesatuan yang menjadi milik komunitas suatu agama tertentu. Klaim identitas ini yang kemudian menumbuhkan semangat egosektoral. Fanatisme ini ditunjukkan pada komunitas umat beragama, misalnya pemaknaan sepihak tentang konsep jihad 
dalam kajian Islam dan perang suci menurut Kristen. Kajian tentang konsep jihad ini dapat dilihat penggunaannya dalam literatur muslim klasik dan berdasarkan sejarah dan historiografi Islam.

Kompleksitas makna jihad kemudian dapat dilihat dari dua sudut pandang, baik pemaknaan secara konvensional maupun modern. Pemaknaan secara konvensional, jihad diartikan dengan perang atau jihad besar. Makna ini menempatkan jihad pada pemaknaan historis (Engineer, 2004, hal. 100). Pemaknaan secara historis ini memerlukan kajian mendalam terkait kondisi sosial dan kultur masyarakat Arab pra-Islam saat itu. Konstruksi masyarakat Arab pra-Islam pada saat itu memiliki tradisi dan adat kesukuan yang mengabaikan etika. Pada masa itu, seakan masih memberlakukan hukum rimba. Karena belum ada aturan hukum, sehingga mengakibatkan setiap permasalahan diselesaikan dengan perang antar suku yang sering berakibat pada maraknya pertumpahan darah (Engineer, 2004, hal. 100). Sedangkan pemaknaan jihad secara modern, jihad dimaknai perang melawan hawa nafsu (jihad al-nafs), sebagaimana dijelaskan al-Ghazali dalam Kitab Ihya' Ulum alDin dengan mengutip beberapa ayat al-Quran dan Hadis Nabi diantaranya adalah QS. an-Nisa ayat 95. Ayat tersebut menjelaskan bahwa Allah melebihkan orangorang yang berjihad dengan harta dan jiwanya atas orang-orang yang duduk (AlGhazali, 2001, hal. 27). Selain melawan hawa nafsu, juga penting diimbangi dengan itikad untuk memajukan agama Islam serta amar ma'ruf nahi munkar. Sedangkan dalam kajian sejarah umat Kristen, fanatisme yang berlebihan ini juga ditunjukkan dalam pemaknaan perang suci yang terjadi pada tahun 1096-1291 yang dikenal dengan perang salib. Perang Salib tersebut merupakan ekspedisi militer Kristen yang mempergunakan salib sebagai simbol pemersatu umat Kristen (Hitti, 1974, hal. 635-636).

Sedangkan faktor eksternal yang berasal dari luar agama, terkait dengan faktor kepentingan suatu kelompok agama dapat berupa politik, ekonomi dan sosial (Rahardjo, 1999, hal. 178). Faktor tersebut justru banyak pihak menilai menjadi alasan yang sebenarnya dibalik konflik yang berbungkus agama. Faktor politik menjadi alasan untuk perebutan kekuasaan dan faktor ekonomi menjadi alasan untuk memperebutkan lahan dan sumber ekonomi dan faktor sosial merupakan manifestasi kecemburuan sosial karena merasa hanya golongan tertentu saja yang banyak diuntungkan keadaan. Misalnya konflik yang terjadi di Poso pada tahun 1998. Awal munculnya konflik di Poso ini adalah karena pertikaian pemuda namun rentan dengan muatan politik berkaitan dengan suksesi bupati. Ketidakpuasan politik inilah yang menjadi akar permasalah konflik. Maka dalam berbagai konflik yang mengatasnamakan agama harus diteliti terlebih dahulu apakah benar agama sebagai faktor dibalik konflik tersebut karena konflik antar umat beragama itu sengaja didesain atau direkayasa oleh kelompok tertentu atau kekuatan tertentu untuk menjadikan masyarakat tidak stabil. Ketidakstabilan masyarakat ini kemudian dimanfaatkan untuk tujuan-tujuan politis dan ekonomis. 


\section{Pendidikan Islam Multikultural sebagai Resolusi Konflik Antar Agama di Indonesia}

Pendidikan Islam multikultural merupakan pengembangan dari prinsip pendidikan multikultural yang mengadopsi dari nilai yang terkandung dalam sumber rujukan Islam, yaitu al-Quran dan Hadis, atau dapat juga didefinisikan sebagai proses transformasi dan internalisasi nilai-nilai dasar dan ideal ajaran Islam yang berusaha mengakomodir aspek-aspek perbedaan dan disparitas kemanusiaan sebagai sunnatullah yang harus diterima dengan penuh arif dan lapang dada di tengah realitas manusia yang plural multikultural dalam berbagai dimensinya untuk mencapai tatanan kehidupan yang berkeadilan(Suryana dan Rusdiana, 2015, hal. 325).

Secara tegas Undang-Undang Sistem Pendidikan Nasional No. 20 Tahun 2003 Pasal 4 menyebutkan bahwa: pendidikan diselenggarakan secara demokratis dan berkeadilan serta tidak diskriminatif dengan menjunjung tinggi hak asasi manusia, nilai keagamaan, nilai kultural, dan kemajemukan bangsa. Jadi dalam pendidikan, nilai-nilai keagamaan tetap menjadi dasar acuan penyelenggaraan pendidikan.

Sedangkan nilai-nilai Islam yang melandasi pelaksanaan pendidikan multikultural adalah: pertama, nilai toleransi. Toleransi merupakan suatu keharusan untuk mewujudkan suatu masyarakat yang bersatu dalam bingkai NKRI (Negara Kesatuan Republik Indonesia). Dasar sikap toleran dan pluralis seorang muslim terhadap agama dan pemeluk agama lain telah mendapat legitimasi berdasarkan ayat-ayat al-Quran, hadis nabi dan fatwa dari sahabat-sahabatnya (Guillaume, 1970, hal. 231).

Dalam sejarah peradaban Islam mencatat bahwa semasa Rasulullah memimpin Negara Madinah, beliau telah meletakkan dasar-dasar pluralisme dan toleransi. Hal tersebut diperlihatkan pada sikap toleransi beliau dapat berdampingan dengan kelompok-kelompok yang berbeda dalam satu negara, misalnya kelompok masyarakat Yahudi, Nasrani dan Majusi. Selain itu, Nabi Muhammadjuga menetapkan kebijakan penggunaan Piagam Madinah sebagai dasar konstitusi negara. Piagam madinah tersebut juga memuat hubungan dan perlindungan terhadap kelompokkelompok yang berbeda tersebut. Nabi Muhammad juga merealisasikan konsep ummah wahidah (ummat yang tunggal) tanpa membedakan agama dan suku warga negaranya, termasuk mengatur hak dan kewajiban warga Madinah secara adil dalam Piagam Madinah tersebut.

Kedua, nilai Perdamaian, yang digambarkan dalam sebuah ayat al-Quran QS. al-Anfal ayat 61 yang artinya:

"Dan jika mereka (musuh) condong ke perdamaian, maka condongkanlah kepadanya dan bertawakkal kepada Allah" (QS. al-Anfal: 61).

Ayat tersebut menekankan pada upaya perdamaian sebagai pilihan pada saat terjadinya konflik. Sehingga nilai perdamaian tersebut menjadi nilai ideal yang disampaikan ajaran Islam sebagai dasar dalam kehidupan bermasyarakat dan berbangsa. 
Nilai tentang perdamaian secara eksplisit menyatu dengan makna Islam itu sendiri yang berarti damai, pasrah. Kualitas kepasrahan tersebut indikatornya adalah sejauhmana kehidupan seorang muslim mampu memberikan dan menjamin perdamaian bagi keberlangsungan hidup manusia. Perdamaian ini digambarkan dalam bentuk suasana nyaman, bebas dari gangguan pihak lain, jauh dari suasana permusuhan, dendam, kebencian dan perilaku yang membuat pihak lain tidak nyaman (Rahman, 2011, hal. 101).

Ajaran Islam dalam ayat-ayat al-Quran maupun Hadis Nabi, tidak ada yang menyerukan kebencian, permusuhan, pertentangan atau perilaku yang mengancam stabilitas kedamaian, karena Islam datang dengan prinsip kasih sayang (mahabbah), kebersamaan (ijtima'iyyah), persamaan (musawah), keadilan ('adalah) dan persaudaraan (ukhuwah) (Rahman, 2011, hal. 102).

Ketiga, nilai penghargaan terhadap keberagaman, merupakan salah satu nilai pendidikan multikultural yang telah digariskan dalam teks al-Quran, yaitu QS. alHujurat, ayat 13 yang artinya:

"Hai Manusia, sesungguhnya kami menciptakan kamu dari seorang lakilaki dan seorang perempuan yang menjadikan kamu berbangsa-bangsa dan bersuku-suku supaya kamu saling kenal mengenal. Sesungguhnya orang yang paling mulia diantara kamu di sisi Allah adalah orang yang paling bertaqwa. Sesungguhnya Allah maha mengetahui lagi maha mengenal". (QS. al-Hujurat: 13).

Ayat di atas menjelaskan bahwa adanya keberagaman dalam masyarakat. Tujuan dari penciptaan keberagaman tersebut adalah untuk saling mengenal antara satu suku ke suku yang lain, dari suatu bangsa yang satu ke bangsa yang lain, untuk saling belajar dan berkontribusi positif, tidak ada diskriminasi, subordinasi, dan alienasi.

Dalam konteks kehidupan berbangsa dan bernegara Islam menerima keberagaman untuk saling bersinergi satu sama lain, sehingga dengan berbekal adaptasi dan akomodasi kebudayaan, Islam dapat dengan mudah diterima oleh seluruh lapisan masyarakat.

Hal di atas menjelaskan bahwa Islam sangat akomodatif terhadap keberagaman. Sehingga, dengan menghayati dan mengamalkan nilai-nilai multikultural dalam ajaran Islam, menjadikan pemikiran lebih terbuka saat dihadapkan pada kenyataan adanya perbedaan. Selain itu juga dapat menanggapi perbedaan dengan cara yang lebih dewasa, bijaksana, dan merespon positif adanya keberagaman tersebut.

Pendidikan Islam multikultural dapat dijadikan media resolusi konflik. Upaya yang dapat dilakukan adalah dengan mensosialisasikan, nilai-nilai multikulturalisme sebagai bagian dari nilai yang terkandung dalam ajaran Islam yang harus ditaati dan dilaksanakan. Sosialisasi tersebut dapat dilaksanakan dalam proses kegiatan belajar mengajar maupun dalam bentuk keteladanan sikap sebagai bentuk internalisasi nilai-nilai multikultural tersebut dalam kultur sekolah dan kegiatan lain di sekolah. Secara praktis, pelaksanaan pendidikan Islam multikultural tersebut dapat dilakukan 
bertahap melalui proses perencanaan pembelajaran yang meliputi pemetaan standar kompetensi, kompetensi dasar, indikator ketercapaian kompentensi, materi ajar, alokasi waktu, metode pembelajaran dan rencana teknik evaluasi yang digunakan. Setelah beberapa komponen yang diperlukan dalam pembelajaran direncanakan dengan baik, kemudian diaplikasikan dalam kegiatan belajar mengajar. Setelah itu dapat diukur tingkat keberhasilannya melalui evaluasi pembelajaran.

Implementasi pendidikan Islam multikultural tersebut dapat dijalankan melalui proses pembelajaran di lembaga pendidikan, kegiatan ekstrakurikuler dan perilaku sehari-hari. Untuk mencapai hasil yang maksimal, implementasi pendidikan Islam multikultural ini juga harus didukung oleh lembaga pendidikan yang lain, yaitu pendidikan keluarga dan pendidikan dalam masyarakat.

\section{Implementasi Pendidikan Islam Multikultural sebagai Resolusi Konflik Antar Agama di Indonesia}

Pendidikan Islam multikultural sebagai resolusi konflik antar agama di Indonesia dalam implementasinya dapat menggunakan beberapa pola pendekatan dalam proses penyelenggaraan pendidikan. Pendekatan tersebut diterapkan dengan cara mengintegrasikan nilai-nilai multikultural dalam Islam melalui beberapa hal berikut:

Pertama, integrasi pendidikan Islam multikultural dalam materi pembelajaran. Materi pembelajaran merupakan komponen yang penting dalam proses pendidikan. Melalui materi pembelajaran, siswa mampu memahami konsep pendidikan multikultural melalui pengenalan beberapa konsep yang lebih operasional dari nilai-nilai pendidikan Islam multikultural tersebut. Konsep yang lebih operasional tersebut diantaranya adalah: Ta'aruf (saling mengenal). Sebagaimana diketahui bahwa di Indonesia memiliki masyarakat yang beragam dalam hal agama, budaya, ras dan etnis. Konsep ta'aruf ini memberi penekanan bahwa keberagaman tersebut dapat dimanfaatkan sebagai media untuk saling mengenal, saling mengisi, saling menghormati dan saling bekerjasama.

Kemudian konsep Takrim (saling menghormati). Artinya bahwa secara universal, setiap agama di Indonesia memiliki ajaran tentang saling menghormati, termasuk saling menghormati antar umat beragama. Konsep takrim ini direalisasikan dalam bentuk toleransi antar umat beragama sebagaimana ajaran tentang lakum diinukum waliaddiin yang termaktub dalam al-Quran Surat al-Kafirun Ayat 6.

Selanjutnya konsep Fastabiqul Khairat (berlomba-lomba dalam kebaikan). Perbedaan agama di Indonesia hendaklah menjadi media bagi umat beragama untuk saling berinteraksi dan berkompetisi dalam hal kebaikan, saling meningkatkan kualitas diri demi mencapai prestasi yang gemilang. Konsep fastabiqul khairat tujuannya tetap satu yaitu dapat memberikan kontribusi yang positif terhadap agama, nusa dan bangsa. Kemudian konsep husnuzhan (berbaik sangka). Konsep husnuzhan ini diartikan dengan berfikir positif terhadap setiap aktivitas dan interaksi antar umat beragama, tidak main hakim sendiri dan mengedepankan dialog untuk menyelesaikan masalah yang terjadi antar umat beragama. 
Terakhir konsep islah (resolusi konflik). Konsep islah ini diartikan dengan mencari titik temu dan jalan keluar yang baik dalam setiap perselisihan antar umat beragama, karena dalam setiap timbulnya konflik perlu ada klarifikasi dari berbagai pihak yang bersengketa dan kemudian mencari solusi bersama. Tujuannya adalah perdamaian dan kerukunan antar umat beragama.

Kedua, integrasi pendidikan Islam multikultural dalam kultur dan budaya sekolah. Sekolah merupakan lembaga pendidikan yang diharapkan masyarakat dapat menanamkan nilai-nilai kebaikan sesuai dengan norma yang dijunjung tinggi oleh agama dan masyarakat. Sehingga, dalam hal ini nilai-nilai pendidikan Islam multikultural yang telah ditanamkan dapat diterapkan di lembaga pendidikan tersebut serta melandasi perilaku, kebiasaan sehari-hari dan simbol-simbol yang dipraktekkan oleh setiap stakeholder sekolah, mulai dari kepala sekolah, guru, petugas administrasi, siswa dan masyarakat lingkungan sekolah. Pendidikan sebagai proses pembudayaan nilai-nilai multikultural dapat dimulai pada lingkup lingkungan pendidikan, selanjutnya dapat diterapkan pada lingkup yang lebih luas dalam kehidupan bermasyarakat, khususnya dalam hubungan antar umat beragama di Indonesia.

\section{Simpulan}

Indonesia sebagai negara multikultural mempunyai banyak potensi untuk mengembangkan kemajuan dalam berbagai bidang. Perbedaan budaya tersebut apabila dikelola dengan baik diharapkan mampu memperkokoh persatuan dan mempercepat tercapainya tujuan yang diharapkan. Namun, yang diidealkan tersebut masih berada dalam proses, sehingga realitasnya masih banyak dijumpai munculnya konflik dengan berbagai latar belakang dan sebab pemicunya, baik konflik antar individu, kelompok, ras, golongan termasuk konflik antar agama.

Agama dalam posisinya sebagai pedoman hidup seharusnya mampu menjadi pemersatu dan perekat sosial khususnya bagi masyarakat yang majemuk, karena dalam agama ada ajaran tentang solidaritas antar umat beragama. Faktanya banyak konflik agama yang justru disebabkan oleh faktor lain di luar agama. Faktor kepentingan politik, sosial dan ekonomi lebih dominan. Agama seakan hanya dijadikan kambing hitam untuk membungkus kepentingan lain.

Indonesia sebagai negara yang mengakui perbedaan agama pada hakekatnya mencita-citakan suatu masyarakat bertuhan dan beragama. Tetapi agama-agama tersebut dapat hidup berdampingan dan berperan secara konstruktif, loyalitas utama kelompok-kelompok agama tidak hanya pada agamanya sendiri. Solidaritas pun lebih mudah dibangun di antara kelompok lintas agama yang memiliki jiwa keindonesiaan yang sama dalam semangat Bhineka Tunggal Eka.

Seiring dengan perkembangan zaman dan ilmu pengetahuan, semakin dapat terlihat jelas upaya yang dilakukan beberapa pihak yang bertujuan untuk meminimalisir adanya konflik sebagai akibat masyarakat Indonesia yang majemuk. 
Strategi yang dapat dilakukan adalah melakukan pendekatan kepada masyarakat dengan menanamkan pendidikan Islam multikultural sebagai salah satu alternatif resolusi konflik antar agama di Indonesia.

Islam sebagai agama yang rahmatan lil alamin telah memberikan dasar pegangan bagi kehidupan yang multikultural melalui ajaran tentang perdamaian, penghargaan terhadap keberagaman, nilai-nilai toleransi, nilai kasih sayang (mahabbah), kebersamaan (ijtima'iyyah), persamaan (musawah), keadilan ('adalah) dan persaudaraan (ukhuwah). Sehingga, nilai-nilai pendidikan Islam multikultural tersebut perlu diimplementasikan dalam ketiga ranah pendidikan, yaitu pendidikan di sekolah, pendidikan keluarga dan pendidikan di masyarakat. Implementasi serius terhadap pendidikan Islam multikultural tersebut diharapkan mampu menjadi alternatif resolusi konflik agama di Indonesia. 


\section{Referensi}

Abed, S. B. (1993). Democracy and The Arab World. Pakistan: Priceton University Press.

Al-Ghazali. (2001). Ihya' Ulum al-Din. Beirut: Dar al-Kutub al-Ilmiyah.

Arifin, H. M. A. (2011). Ilmu Pendidikan Islam: Tinjauan Teoretis dan Praktis Berdasarkan Pendekatan interdisipliner. Jakarta: Bumi Aksara.

Banks, J. A. (1993). An Introduction to Multicultural Education. Boston: Allyn and BaconPress.

Bennet, C. I. (1995). Comprehensive Multicultural Education: Theory and Practice. Massachused: A Simon \& Schuster Company.

Effendy, B. (2001). Masyarakat Agama dan Pluralisme Keagamaan. Yogyakarta: Galang Press.

Engineer, A. A. (2004). Liberasi Teologi Islam: Membangun Teologi Damai dalam Islam. Yogyakarta: Alinea.

Guillaume, A. (1970). The Life of Muhammad. Lahore: Oxford University Press.

Hilmy, M. (2003). Menggagas Paradigma Pendidikan Berbasis Multikultural. Ulumuna, 7(2)

Hitti, P. K. (1974). History of The Arab. London: The Mac Millan Press. London.

Huntington, S. P. (1998). The Clash of Civilization and The Remaking of World Order. London: Thouchstone.

Iqbal, M. (1960). The Reconstruction of Religius Thought in Islam. Pakistan: Institute of Islamic Culture Lahore.

Lash, S., \& Featherstone, M. (ed.). (2002). Recognition and Difference: Politics, Identity, Multiculture. London: Sage Publication.

Mahfud, C. (2006). Pendidikan Multikultural. Yogyakrata: Pustaka Pelajar.

Musahadi (Ed.). (2007). Mediasi dan Resolusi Konflik di Indonesia. Semarang: WMC. Semarang.

Purwanto, N. (2011). Ilmu Pendidikan Teoretis dan Praktis. Bandung: PT. Remaja Rosdakarya.

Rahardjo, D. (1999). Masyarakat Madani: Agama, Kelas Menengah dan Perubahan Sosial. Jakarta: LP3ES.

Rahman, B. M. (Ed.). (2011). Islam dan Liberalisme. Jakarta: Friedrich Naumann Stiftung. 
Saebani, B., \& Akhdiyat, H. (2012). Ilmu Pendidikan Islam. Bandung: CV Pustaka Setia.

Suryana, Y., \& Rusdiana. (2015). Pendidikan Multikultural: Suatu Upaya Penguatan Jati Diri Bangsa,Konsep-Prinsip-Implementasi. Bandung: CV. Pustaka Setia.

Taylor, C. (1994). The Politic of Recognation. Dalam Amy Gutman, Multiculturalism, Examining the Politic of Recognation. Princention: Princention University Press.

Tilaar, H. A. R. (2015). Pedagogik Teoretis untuk Indonesia. Jakarta: Kompas.

Undang-Undang Sistem Pendidikan Nasional No. 20 Tahun 2003.

Yusuf, R. (2011). Pendidikan dan Investasi Sosial. Bandung: Alfabeta. 